\title{
Teachers Application of the National Professional Standards in Three Northern Jordanian Provincial Schools
}

\author{
Saleh Swailem Alshurfat ${ }^{1, *}$ \\ ${ }^{1}$ Department of Administration and Foundation of Education, Faculty of Educational Sciences, \\ Al alBayt University, PO Box: 130040 Mafraq 25113, Jordan \\ *Correspondence: Department of Administration and Foundation of Education, Faculty of \\ Educational Sciences, Al alBayt University, PO Box: 130040 Mafraq 25113, Jordan. Tel: \\ 962-779-604-699. E-mail: alsharafat2013@gmail.com
}

Received: October 15, 2015 Accepted: December 31, 2015 Published: February 10, 2016

doi:10.5296/ije.v8i1.8430 URL: http://dx.doi.org/10.5296/ije.v8i1.8430

\begin{abstract}
The main purpose of this study was to explore and analyze primary school teachers' perceptions at three Northern provinces about the application of national professional standards for teachers. A questionnaire, which was based on the National Professional Standards for Jordanian Teachers, was developed by a national and international team of experts in (2006) as an integral part of the Jordanian educational reform program. The questionnaire included seven scales containing (56) items. Participants were asked to respond to each item statement using a five-point Likert scale. The study surveyed (632) teachers at three Northern provinces. Both descriptive and inferential statistical procedures were employed to analyze the data from the questionnaire survey. The main findings indicate that, in general, teachers are moderately satisfied with their professional standards.
\end{abstract}

Keywords: Teacher standards, Educational reform, Jordan 


\section{Introduction}

The rapid change and increased complexity of today's world present new challenges' and a new demands on the Jordanian educational system. Education and the quality of its provision are a means to secure advantage in the global market (Giroux, 2008; Spring, 2009; Shirazi, 2010). Reform has become a strategy based on the belief in the power of education as an instrument for social engineering and the creation of economic growth (Alayan, Rohde, \& Dhouib, 2012). The prominence and scope of interest in this topic are illustrated by the following remark: " .. everywhere, it seems, educational change is not only a policy priority but also major public news" (Hargreaves, Lieberman, Fullan \& Hopkins, 1998, p.1).

Change has occurred very quickly due to the significant impact of scientific and technological advancements in human civilization. As a result, to keep abreast with the changes, teachers must be well-equipped with the necessary knowledge and skills to ensure that curriculum emphases are realized in the classroom. In other words, teachers must deliver their lessons effectively as envisaged in the curriculum (Kubow, 2010; Porter, Fursarelli \&Fursarelli, 2015).

In many respects schools become the last resort of society because they are expected to solve the problems that other societal institutions seem unwilling or unable to treat (Hargreaves, 2009). Teachers hold a pivotal position in the success of schools. Moreover, teachers are key change leaders as it is they who are instrumental in making educational change work for students (Fullan, 2001; Santoro\&Kennedy, 2015).

Teachers' work is being evaluated as never before (OECD, 2012). Measures of teacher capacity are gathered, while national and international studies assess outcomes. These data are used to advance theoretical and political agendas that reflect a concern for teacher professional practice as much as they do for student achievement. The teaching profession is increasingly challenged by accountability and standards adopted by governments as keys for school improvement (Kelchtermans, 2007; Comber \& Nixon, 2009; Caldwell, 2010; Tuinamuana, 2011; Blatchford, 2013; Witte\&Jansen, 2015).

The Queensland Board of Teacher Registration (2002) argued that professional standards are a prerequisite for any system of education where teachers need to be recognized as possessing the necessary attributes, skills and knowledge required of members of the profession. It maintained that although recognized professional standards should be judged by performance assessement, the priority of such standards must be the focused performance of teachers. Moreover, the establishment of standards and their implementation should be established on a number of pillars such as those mentioned by Brocks (2000):

- The identification of any professional standards must involve full discussion with and ultimately ownership of such standards by the teaching profession.

- Accomplished teachers make a difference in students' learning and performance.

- Any attempt to establish professional teacher standards must be firmly grounded in the accurate and comprehensive understanding of both the timeless and evolving nature of the work of the teacher. 
- Professional standards should emphasize the concept of a career-long continuum of development through all of the work cycles of teachers.

- The articulation and commitment to professional standards should be flexible enough to celebrate of the quality of individuality which is a benchmark of being a professional.

- Finally, teachers should also have an axial role in implementing these standards (Sachs, 2003; Alshawa, 2012).

\section{Study Background}

The education system in Jordan, as well as in many other countries, has undergone considerable change over the last 20 years with respect to the restructuring of the years of schooling, the modification of the teaching practice, the improvement in curricula and textbooks, the upgrade in teacher's qualifications, and the increased involvement of stakeholders in the education process (Frey, 2014).

In response to the need for education reform, the government of Jordan called for the reform of education to meet the needs of the country and its people (Ministry of Education, 2012). In 1987, the Government launched the first Jordanian Reform Education Program (JERP), an ambitious, 25 year-long, comprehensive education reform program (Quota, 2014). The ultimate goal was to improve the quality of the outcomes produced by the education system (Ministry of Education, 2013). Major programs in this national reform project involved changes in curriculum and textbooks, updating teaching strategies to include activity-based learning and group work, accommodating the needs of special education students, greater use of information technology, and additional teacher education and training (Phoenix Center for Economics and Informatics Studies, 2014).

Within Jordan, teachers were seen as being central to the change process both as facilitators of change and as the group that would be most affected by change. Thus, any change was likely to have a significant impact on teachers' work. The effect of reforms on teachers' work has been the subject of extensive study in many countries (Alshorfat, 2012).

Hargreaves and Goodson (1996) question the nature of teachers' professional work in the postmodern technologically driven world:

Alongside the accelerating changes in global and domestic economies, have teachers' skills and responsibilities changed in ways that really matter? Are the shifts more than cosmetic; more than a gloss for extra administration and busywork? Is teachers' work becoming increasingly more complex or is it just more extended and in overload? (p. 17).

Similarly, the Jordanian Education Reform Program stressed the centrality of teachers and the importance of their work in making change happen and it required teachers to change their practice while placing upon them new demands and standards (Sakarneh, 2014). Professional standards have become increasingly important everywhere (Witte, \& Jansen, 2015). 
Developing teachers' standards was identified as an important central aspect of this education reform program. It assumed standards have a central position in changing the behavior of teachers.

\section{The Teacher Standards Experiment in Jordan}

In recent years, the push for the development and promulgation of teacher standards has been a worldwide phenomenon (Nasta, 2007; Townsend \& Bates, 2007; Harris, Moran, \& Long, 2010). "Standards-based reform" of teacher education is seen as a way of professionalizing teaching, strengthening the preparation of teachers, and improving schools' outcomes by linking to the K-12 standards' movement (O'Shea, 2005; Olson, 2007, Daraiseh, 2014).

This movement appeals to a broad spectrum of advocates: those who want better accountability systems in teacher education (Wise, 2004; Cuban, 2007), those who promote learner-centered teaching (Darling-Hammond, 2004), and those who question the teacher-testing movement (Reynolds, 2005). The emphasis on standards has become central to policy discussions about education. Teacher selection, promotion, reward, and development have all been debated in terms of standards (Romanowski, 2014).

Discussions of these issues can be found in many developed countries including, for example, the United States(Eberts, Hollenbeck \& Stone, 2002), Australia (Ingvarson \& Kleinhenz, 2006; Meiers, 2006), and most European countries (Storey, 2006; Bulmahn, 2004). Additionally, nation-states with a variety of economic and political systems have also debated the links between standards and national competitiveness.

In recent years, efforts have been made in Jordan to develop a centralized system of teaching standards, and a team of national and international expertise has been formed. This team was charged with the task of developing nationwide standards that reflect what teachers are expected to know and be able to do at all stages of their carriers. The Ministry of Education adopted National Professional Standards for teachers (hereafter NPST) in 2006.

\section{Aim of the Study}

The aim of this study was to investigate teachers' perceptions of the application of NPST. The following research objectives were formulated for the sake of approaching the research problem:

Objective 1: to measure teachers' perceptions of the application of NPST.

Objective 2: to determine whether or not any differences exist in teachers' perceptions according to their gender or their school's location. 


\section{Significance of the Study}

Teachers are instrumental in translating content standards into teachable classroom lessons. However, not a single research study has examined the perception and practice or understanding of teachers for the NPST. The study reported here has tried to fill the gap between policy intent and the lack of research-based knowledge on teachers' perceptions of the policy's effects. Furthermore, it will contribute to the development of teachers' perception and their implementation of these standards. Moreover, these results provide an important source of information for educators, policy makers, and researchers who have the responsibility for creating educational policy and planning for a more modern educational system in the years to come.

\section{Methodological Approach}

In this study, a survey was conducted of teachers in a sample of schools. Surveys are the most widely used method of data collection in education (Fowler, 2013). A questionnaire survey was clearly the most efficient way to solicit the views of a large number of teachers distributed across a large geographic area. Such surveys have been firmly established as a viable means for gathering valid and reliable data (Creswell, 2013). Survey research can be very valuable as it is best adapted to obtaining personal and social facts, beliefs, and attitudes (Frankel \&Wallen, 2006).

\subsection{The Sample}

Table 1. Description of the Study Sample

\begin{tabular}{cccc}
\hline Variables & Defined Variables & Frequencies & Percent \\
\hline \multirow{3}{*}{ Province } & Mafraq & 175 & 27.7 \\
& Irbid & 321 & 50.8 \\
& Jarash & 136 & 21.5 \\
\multirow{3}{*}{ Gender } & Male & 314 & 37.0 \\
& Female & 398 & 63.0 \\
School location & Urban & 314 & 65.5 \\
& Rural & 318 & 34.5 \\
Years of teaching experience & $0-5$ & 159 & 25.2 \\
& $6-10$ & 183 & 29.0 \\
Total & 11 above & 290 & 45.8 \\
& 632 & & 100.0 \\
\hline
\end{tabular}

Sample obtained in the study was randomly selected from among all primary school teachers in three Northern provinces of Jordan: Mafraq, Irbid, and Jarash. In those provinces, forty-six 
primary schools were selected to ensure that the sample used in this study was representative of all types of schools (urban and rural, large and small). Therefore, a total of 800 questionnaires were sent out to these forty-six schools which included urban as well as rural schools of the provinces of Mafraq, $(n=175)$ teachers percent 27.7, Irbid, $(n=321)$ teachers percent 50.8 and Jarash, $(n=136)$ teachers percent 21.5. A total of $(n=632) .98$ percent of the questionnaires were returned. A total of 63 percent of the research participants were female and 37 percent were male. Also, 65.5 percent of the participants were teachers in urban schools and 34.5 percent were teachers in rural schools.

\subsection{Research Instrument}

The survey instrument consisted of 56 items grouped into seven scales, all of which were taken directly from the NPST list developed by Ministry of Education, (Ministry of Education, 2006). The seven categories of skills represented in the questionnaire were (a) education in Jordan (8 items); (b) content and special pedagogical knowledge (6 items); (c) lessons planning (6 items); (d) implementing lessons planning (9 items); (e) assessment of students' learning and lesson effectiveness (10 items); (f) professional development ( 7 items); and ( $\mathrm{g}$ ) teachers' professional ethics (10 items).

It was necessary to ensure that the generated items reflected the theoretical constructs of disposition, knowledge, and skills underlying every scale of standards for teachers, that is, that the scale had content validity. To this end, 10 teacher educators in Jordanian universities were asked to check the content validity and to provide critical feedback on the written survey items. To assess the internal consistency and reliability of the total scale and sub scales of the NPST, the Cronbach alpha coefficient was used to analyze the data of 632 cases. An alpha reliability higher than 90 indicated a high degree on internal consistency.

To complete the survey, teachers were asked first to complete the demographic background information including questions regarding gender, school location, years of experience and then, using a five-point Likert scale, rate their impressions of the application of NPST. Responses were coded as follows: 1 strongly disagree, 2 disagree, 3 neutral, 4 agree, 5 strongly agree. The questionnaire was administered in June 2014.

\subsection{Data Analyses}

After collecting and coding the survey data, statistical analyses were conducted using version 16 of the Statistical Package for the Social Sciences (SPSS). The seven scales provided interval data so descriptive statistical procedures were employed in the analysis. More specifically, means, medians, and standard deviations were calculated and analyzed for each one of the sixty-five item statements that comprised the first research question, which was focused on the examination of the teachers' views on the seven aspects. Teachers' responses concerning the seven aspects of the climate of their school were examined. For background categorical variables, tests of significance of differences were carried out using $t$ test and Analysis of Variance (ANOVA). The $(\alpha=0.05)$ level of probability was adopted as the criterion of statistical significance. The following scale was used in making judgments about the degree of application indicated in responses: (1-1.49) very low application; (1.50-2.49) low application; 
(2.50-3.49) moderate application; (3.50-4.49) high application; (4.50) and above very high application.

\section{Results}

\subsection{Teachers' Perceptions of the Implementation of NPST}

It is clear from Table 2, that teachers reported high application of the standards of "Education in Jordan." The mean of standard items ranged from (3.77) to (4.22) and the overall mean score was (4.10) on the 5-point scale.

Table 2. Mean and Standard Deviation for the Items on the Standard of Education in Jordan

\begin{tabular}{|c|c|c|c|}
\hline Item No. & Item statement & Mean & SD \\
\hline 1. & $\begin{array}{l}\text { I demonstrate an understanding of foundations of the } \\
\text { educational system in Jordan. }\end{array}$ & 4.22 & 1.02 \\
\hline 2. & $\begin{array}{l}\text { I demonstrate knowledge of the bases of education in } \\
\text { Jordan. }\end{array}$ & 4.18 & 1.15 \\
\hline 3. & $\begin{array}{l}\text { I demonstrate understanding of goals of education in } \\
\text { Jordan. }\end{array}$ & 4.16 & 1.18 \\
\hline 4. & $\begin{array}{l}\text { I demonstrate knowledge of educational legislation related } \\
\text { to my work. }\end{array}$ & 4.12 & 1.13 \\
\hline 5. & I demonstrate knowledge of the educational context. & 4.06 & 1.04 \\
\hline 6. & I demonstrate understanding of the school curriculum. & 4.03 & 1.14 \\
\hline 7. & $\begin{array}{l}\text { I demonstrate understanding of learning outcomes } \\
\text { pertinent to the subject(s) that I teach. }\end{array}$ & 3.89 & 1.23 \\
\hline \multirow[t]{2}{*}{8.} & $\begin{array}{l}\text { I demonstrate understanding of educational change } \\
\text { processes in Jordan. }\end{array}$ & 3.77 & 1.19 \\
\hline & Mean & 4.10 & 1.14 \\
\hline
\end{tabular}

As can be seen in Table 3, teachers reported moderate degrees of "application of content and special pedagogical knowledge standard" all scale items with means ranging from 2.88 to 3.34 and high degrees of application for the remaining two items (3.88 and 4.22) with the overall mean score of 3.18 . 
Table 3. Mean and Standard Deviation for the Items in the Standard Content and Special Pedagogical Knowledge

\begin{tabular}{|c|c|c|c|}
\hline Item No. & Item statement & Mean & SD \\
\hline 9. & $\begin{array}{l}\text { I demonstrate understanding of content of the discipline(s) or } \\
\text { subject(s) that I teach and its transformation in to learnable } \\
\text { forms. }\end{array}$ & 3.18 & 1.09 \\
\hline 10 . & I have solid knowledge of my subject matter. & 3.21 & 1.29 \\
\hline 11. & $\begin{array}{l}\text { I demonstrate understanding of modes/ ways of thinking } \\
\text { pertinent to the subject(s) that I teach. }\end{array}$ & 3.34 & 1. 42 \\
\hline 12. & $\begin{array}{l}\text { I have knowledge of relations among my teaching subject (s) } \\
\text { and other subjects. }\end{array}$ & 3.28 & 1.18 \\
\hline 13. & $\begin{array}{l}\text { I have basic knowledge resources for the subject(s) that I } \\
\text { teach. }\end{array}$ & 3.22 & 1.23 \\
\hline \multirow[t]{2}{*}{14.} & $\begin{array}{l}\text { I introduce subject(s) contents in various styles to facilitate } \\
\text { students' learning. }\end{array}$ & 2.88 & 0.90 \\
\hline & Mean & 3.18 & 1.19 \\
\hline
\end{tabular}

Table 4 shows moderate levels of performance on all items. The overall mean score was 3.35 indicating moderate performance for this standard.

Table 4. Mean and Standard Deviation for the Items in the Standard of Lessons Planning

\begin{tabular}{clcc}
\hline Item No. & \multicolumn{1}{c}{ Item statement } & Mean & SD \\
\hline 15. & $\begin{array}{l}\text { I design coherent instructional plans in light of the intended } \\
\text { learning outcomes and in accordance with the curricula } \\
\text { standards. }\end{array}$ & 2.75 & 0.90 \\
16. $\quad \begin{array}{l}\text { I demonstrate understanding of the principles of student } \\
\text { learning and development and use them in lessons planning. }\end{array}$ & 3.97 & 1.10 \\
17. $\quad \begin{array}{l}\text { I demonstrate knowledge of accessible learning resources, } \\
\text { including those of ICT, and use them in lesson planning. }\end{array}$ & 2.55 & 0.70 \\
18. $\quad \begin{array}{l}\text { I demonstrate knowledge of instructional strategies and } \\
\text { choose those that match the needs of my students. }\end{array}$ & 3.87 & 1.28 \\
19. $\quad \begin{array}{l}\text { I design interactive learning activities, which motivate } \\
\text { students' learning and participating. }\end{array}$ & 2.67 & 1.63 \\
$\quad \begin{array}{l}\text { I organize interactive learning environments characterized by } \\
\text { safety, participation and cooperation. }\end{array}$ & 3.29 & 1.00 \\
& $\quad$ Mean & 3.35 & 1.10 \\
\hline
\end{tabular}

Table 5 indicates that means of the standard items ranged from 2.42 to 4.29 and the overall mean was 3.33 reflecting moderate application of this standard. 
Table 5. Mean and Standard Deviation for the Items in the Standard of Implementing Lessons Planning

\begin{tabular}{|c|c|c|c|}
\hline Item No. & Item statement & Mean & $\mathrm{SD}$ \\
\hline 21. & I develop students' critical and creative thinking skills. & 2.42 & 1.30 \\
\hline 22. & $\begin{array}{l}\text { I am flexible in adapting a teaching plan to the changing } \\
\text { teaching/ learning situations and students' needs. }\end{array}$ & 3.80 & 1.60 \\
\hline 23. & $\begin{array}{l}\text { I use appropriate resources for learning, including ICT } \\
\text { according to students' learning needs. }\end{array}$ & 2.20 & 1.20 \\
\hline 24. & $\begin{array}{l}\text { I organize interactive, safe and supportive learning } \\
\text { environments. }\end{array}$ & 4.29 & 1.50 \\
\hline 25. & $\begin{array}{l}\text { I use appropriate classroom management strategies and } \\
\text { techniques effectively. }\end{array}$ & 3.82 & 1.44 \\
\hline 26. & I deal with students' problematic behavior successfully. & 2.47 & 1.10 \\
\hline \multirow[t]{2}{*}{27.} & $\begin{array}{l}\text { I use appropriate and diverse instructional strategies } \\
\text { effectively. }\end{array}$ & 3.29 & 1.00 \\
\hline & Mean & 3.18 & 1.30 \\
\hline
\end{tabular}

Table 6 shows considerable variation in the levels of reported performance of these items. Means ranged from high on items 30,32, and 34, through moderate on items 31, 35, 37, 38 and 39, to low on items 33 and 36 .

Table 6. Mean and Standard Deviation for the Items in the Standard of Assessment of Students Learning and Lessons Effectiveness

\begin{tabular}{|c|c|c|c|}
\hline Item No. & Item statement & Mean & SD \\
\hline 30. & $\begin{array}{l}\text { I understand the relationships among students' outcomes, teaching } \\
\text { and evaluation of students' learning. }\end{array}$ & 3.55 & 0.89 \\
\hline 31. & $\begin{array}{l}\text { I choose and design a variety of appropriate assessment } \\
\text { techniques to evaluate students' learning. }\end{array}$ & 2.97 & 1.25 \\
\hline 32. & $\begin{array}{l}\text { I design appropriate learning activities based on students' } \\
\text { assessment. }\end{array}$ & 3.89 & 0.97 \\
\hline 33. & I maintain previous records of students' circumstances. & 2.45 & 0.45 \\
\hline 34. & $\begin{array}{l}\text { I communicate with students' parents about their children's } \\
\text { learning difficulties. }\end{array}$ & 3.65 & 0.29 \\
\hline 35 . & $\begin{array}{l}\text { I analyze students' performance and provide students with } \\
\text { feedback about their performance and progress. }\end{array}$ & 2.77 & 0.82 \\
\hline 36. & $\begin{array}{l}\text { I provide students with opportunities to participate in their } \\
\text { learning evaluation. }\end{array}$ & 1.96 & 0.67 \\
\hline 37. & $\begin{array}{l}\text { I communicate with the school principal and the local education } \\
\text { department about students' learning difficulties. }\end{array}$ & 3.18 & 1.02 \\
\hline 38. & $\begin{array}{l}\text { I use a variety of assessment tools to evaluate my teaching } \\
\text { performance. }\end{array}$ & 3.23 & 0.99 \\
\hline \multirow[t]{2}{*}{39.} & I revise my teaching based on the results of students evaluation. & 3.20 & 0.87 \\
\hline & Mean & 3.42 & .82 \\
\hline
\end{tabular}


On the other hand, as can been seen in Table 7, means of the items in the "standard of professional development" ranged from (1.09) to (3.23) reflecting very low application for this standard. No item in this standard was above (3.50) which also was accompanied by a high standard deviation (1.21). That is, teachers' opinions differed considerably on the items.

Table 7. Mean and Standard Deviation for the Items in the Standard of Professional Development

\begin{tabular}{|c|c|c|c|}
\hline Item No. & Item statement & Mean & SD \\
\hline 40. & $\begin{array}{l}\text { I incorporate information and communication technology into my } \\
\text { professional development. }\end{array}$ & 1.60 & 1.45 \\
\hline 41. & $\begin{array}{l}\text { I use different research strategies as action research to develop my } \\
\text { performance. }\end{array}$ & 1.09 & 1.34 \\
\hline 42. & $\begin{array}{l}\text { I participate in local, state and national professional workshops, } \\
\text { conferences, meetings. }\end{array}$ & 2.22 & 1.34 \\
\hline 43. & I read books, periodicals and academic journals. & 2.66 & 1.29 \\
\hline 44. & $\begin{array}{l}\text { I participate in professional development activities on school and local } \\
\text { levels. }\end{array}$ & 2.98 & 1.23 \\
\hline 45. & $\begin{array}{l}\text { I collaborative with my school colleagues in developing my professional } \\
\text { development activities. }\end{array}$ & 2.87 & 0.89 \\
\hline \multirow[t]{2}{*}{46.} & $\begin{array}{l}\text { I show high interest in upgrading my academic and professional } \\
\text { qualifications. }\end{array}$ & 2.46 & 0.97 \\
\hline & Mean & 2.27 & 1.21 \\
\hline
\end{tabular}

Finally, Table 8 shows that the standard of teachers' professional ethics was consistently rated highly, $(\mathrm{m}=3.89)$ and standard deviation of only $(\mathrm{SD}=0.78)$

Table 8. Mean and Standard Deviation for the Items in the Standard of Teachers' Professional Ethics

\begin{tabular}{|c|c|c|c|}
\hline Item No. & Item statement & Mean & SD \\
\hline 47. & $\begin{array}{l}\text { I recognize my obligations to improve my effectiveness as a teacher in every possible } \\
\text { way. }\end{array}$ & 3.89 & 0.81 \\
\hline 48. & I treat students fairly, equitably and with dignity and respect. & 4.05 & 0.69 \\
\hline 49. & $\begin{array}{l}\text { I act in a good behavior manner with my colleagues and community, and I serve as a } \\
\text { good role model. }\end{array}$ & 4.56 & 0.72 \\
\hline 50. & I cooperate with parents and community to develop the education system. & 3.79 & 0.86 \\
\hline 51. & I show commitment in using information resources with high ethics and morals. & 4.10 & 0.87 \\
\hline 52. & $\begin{array}{l}\text { I direct my students to use information resources with high professional codes of } \\
\text { ethics and morals. }\end{array}$ & 4.25 & 0.74 \\
\hline 53. & I defend teachers' rights and school rights. & 3.55 & 0.80 \\
\hline 54. & I keep closely to the dress code. & 3.34 & 0.78 \\
\hline 55. & I cooperate with my colleagues and show interest in their professional development. & 3.23 & 0.72 \\
\hline \multirow[t]{2}{*}{56.} & I accept my students and show passion and sympathy through my work with them. & 4.11 & 0.80 \\
\hline & Mean & 3.89 & 0.78 \\
\hline
\end{tabular}


The second study objective was to explore if there are any differences existing in teachers' perception toward the application of national professional standards for teachers based on gender, school location, or years of teaching experience. As the results of Tables 9 and 10 suggest that there were no significant differences among teachers due their gender and school location, it may be explained in light of the fact that both male and female teachers at Northern provinces schools receive the same courses and working under the same conditions in urban and rural schools (Sonbol, 2003).

Table 9. Differences between Male and Female Teachers within each Standard

\begin{tabular}{|c|c|c|c|c|c|c|c|}
\hline Scale No. & standard & Gender & $\mathrm{N}$ & Means & $\mathrm{SD}$ & $\mathrm{T}$ & $\mathrm{P}$ \\
\hline \multirow[b]{2}{*}{1.} & \multirow{2}{*}{ Education in Jordan } & M & 234 & 4.01 & 0.54 & \multirow{2}{*}{0.23} & \multirow{2}{*}{.94} \\
\hline & & $\mathrm{F}$ & 398 & 4.00 & 0.50 & & \\
\hline & Content and special & M & 234 & 3.03 & 0.61 & \multirow{2}{*}{0.58} & \multirow{2}{*}{.71} \\
\hline 2. & pedagogical knowledge & $\mathrm{F}$ & 398 & 3.27 & 0.65 & & \\
\hline \multirow{3}{*}{3.} & \multirow{2}{*}{ Lesson planning } & M & 234 & 3.05 & 0.59 & \multirow{2}{*}{0.21} & \multirow{2}{*}{.54} \\
\hline & & $\mathrm{F}$ & 398 & 3.15 & 0.60 & & \\
\hline & Implementing lessons & M & 234 & 2.29 & 0.66 & \multirow{2}{*}{-.73} & \multirow{2}{*}{.38} \\
\hline 4. & planning & $\mathrm{F}$ & 398 & 2.33 & 0.67 & & \\
\hline \multirow[b]{2}{*}{5.} & Assessment of students' & $\mathrm{M}$ & 234 & 3.21 & 0.65 & \multirow[b]{2}{*}{0.57} & \multirow[b]{2}{*}{.56} \\
\hline & $\begin{array}{l}\text { learning and lesson } \\
\text { effectiveness }\end{array}$ & $\mathrm{F}$ & 398 & 3.18 & 0.62 & & \\
\hline \multirow[t]{2}{*}{6.} & \multirow{2}{*}{ Professional development } & M & 234 & 2.02 & 0.70 & \multirow{2}{*}{-1.23} & \multirow{2}{*}{.73} \\
\hline & & $\mathrm{F}$ & 398 & 2.09 & 0.68 & & \\
\hline \multirow[t]{2}{*}{7.} & \multirow{2}{*}{ Teachers' professional ethics } & M & 234 & 3.29 & 0.45 & \multirow{2}{*}{-4.18} & \multirow{2}{*}{.33} \\
\hline & & $\mathrm{F}$ & 398 & 3.44 & 0.41 & & \\
\hline
\end{tabular}

Table 10. Differences between Teachers based on School Location

\begin{tabular}{|c|c|c|c|c|c|c|c|}
\hline $\begin{array}{l}\text { Scale } \\
\text { No. }\end{array}$ & Standard & \multicolumn{2}{|c|}{$\begin{array}{c}\text { School } \\
\text { location }\end{array}$} & Means & SD & $\mathrm{T}$ & $\mathrm{P}$ \\
\hline \multirow[t]{2}{*}{1.} & \multirow{2}{*}{ Education in Jordan } & urban & 314 & 4.01 & .54 & 0.24 & 0.20 \\
\hline & & rural & 318 & 4.00 & .50 & & \\
\hline \multirow[t]{2}{*}{2.} & Content and special pedagogic & urban & 314 & 3.30 & .61 & 0.60 & 0.71 \\
\hline & Knowledge & rural & 318 & 3.27 & .65 & & \\
\hline \multirow[t]{2}{*}{3.} & \multirow{2}{*}{ Lesson planning } & urban & 314 & 3.05 & .59 & 2.11 & 0.15 \\
\hline & & rural & 318 & 3.15 & .60 & & \\
\hline \multirow[t]{2}{*}{4.} & \multirow{2}{*}{ Implementing lesson planning } & urban & 314 & 2.29 & .66 & -0.76 & 0.74 \\
\hline & & rural & 318 & 2.33 & .67 & & \\
\hline \multirow[t]{2}{*}{5.} & \multirow{2}{*}{$\begin{array}{l}\text { Assessment of students' learning } \\
\text { and lessons effectiveness }\end{array}$} & urban & 314 & 3.71 & .65 & 10.49 & 0.56 \\
\hline & & rural & 318 & 3.18 & .62 & & \\
\hline \multirow[t]{2}{*}{6.} & \multirow{2}{*}{ Professional development } & urban & 318 & 3.02 & .70 & 16.94 & 0.76 \\
\hline & & rural & 318 & 2.09 & .68 & & \\
\hline \multirow[t]{2}{*}{7.} & \multirow{2}{*}{ Teachers' professional ethics } & urban & 314 & 3.29 & .45 & -4.38 & 0.13 \\
\hline & & rural & 318 & 3.44 & .41 & & \\
\hline
\end{tabular}




\section{Macrothink}

As shown in Table 11, a post hoc test of multi comparisons reveals a significant difference in application of the three standards based on teaching experience: implementing lesson planning, assessment of students' learning and lesson effectiveness and professional development). But the test did not indicate which categories were different from others.

Table 11. The Differences between Teachers According to Years of Teaching Experience

\begin{tabular}{|c|c|c|c|c|c|c|c|}
\hline $\begin{array}{c}\text { Scale } \\
\text { No. }\end{array}$ & Standard & \multicolumn{2}{|c|}{ Sum of Squares (SS) } & DF & MS & $\mathrm{F}$ & $\mathrm{P}$ \\
\hline \multirow{3}{*}{1.} & \multirow{3}{*}{ Education in Jordan } & Between groups & 21.80 & 2 & 10.9 & & \\
\hline & & Within groups & 1045.21 & 629 & 1.66 & 6.56 & 0.64 \\
\hline & & Total & 576.01 & 631 & & & \\
\hline \multirow{3}{*}{2.} & \multirow{3}{*}{$\begin{array}{l}\text { Content and special } \\
\text { pedagogical knowledge }\end{array}$} & Between groups & 12.55 & 2 & 6.28 & & \\
\hline & & Within groups & 1558.89 & 629 & 2.48 & 2.53 & 0.71 \\
\hline & & Total & 1615.44 & 631 & & & \\
\hline \multirow{3}{*}{3.} & \multirow{3}{*}{ Lesson planning } & Between groups & 33.00 & 2 & 16.5 & & \\
\hline & & Within groups & 2011.52 & 629 & 3.20 & 5.16 & 0.34 \\
\hline & & Total & 2044.52 & 631 & & & \\
\hline \multirow{3}{*}{4.} & \multirow{3}{*}{$\begin{array}{l}\text { Implementing lesson } \\
\text { planning }\end{array}$} & Between groups & 101.20 & 2 & 50.6 & & \\
\hline & & Within groups & 634.00 & 629 & 1.01 & 50.01 & 0.00 \\
\hline & & Total & 735.20 & 631 & & & \\
\hline \multirow{3}{*}{5.} & \multirow{3}{*}{$\begin{array}{l}\text { Assessment of students } \\
\text { learning and lessons } \\
\text { effectiveness }\end{array}$} & Between groups & 76.22 & 2 & 38.11 & & \\
\hline & & Within groups & 405.00 & 629 & 0.64 & 59.55 & 0.01 \\
\hline & & Total & 481.22 & 631 & & & \\
\hline \multirow{3}{*}{6.} & \multirow{3}{*}{ Professional development } & Between groups & 56.55 & 2 & 28.28 & & \\
\hline & & Within groups & 558.89 & 629 & 0.89 & 31.78 & 0.03 \\
\hline & & Total & 615.44 & 631 & & & \\
\hline \multirow{3}{*}{7.} & \multirow{3}{*}{$\begin{array}{l}\text { Teachers' professional } \\
\text { ethics }\end{array}$} & Between groups & 7.33 & 2 & 3.67 & & \\
\hline & & Within groups & 889.88 & 629 & 1.42 & 2.59 & 0.69 \\
\hline & & Total & 897.21 & 631 & & & \\
\hline
\end{tabular}

To determine where differences existed, a Scheffe post hoc test was conducted. The results are displayed in Table 12. The analysis revealed significant differences between of 0-5 years of teaching experience and the other two categories. Teachers with 0-5 years of teaching experience were more apt to apply the NPST than the teachers with 6-10 years of experience or those with $11+$ years of experience. 
Table 12. Post-hoc test of Multiple Comparisons of Teachers of Differing Years of Teaching Experience

\begin{tabular}{lcc}
\hline \multicolumn{1}{c}{ Standard } & Mean difference & $\mathrm{P}$ \\
\hline Implementing lesson planning & 0.68 & $<.01$ \\
$0-5$ vs 11 and above & $(4.40-3.72)$ & \\
Assessment of students' learning and lesson & 0.77 & $<.01$ \\
effectiveness & $(4.40-2.88)$ & \\
$0-5$ vs 6-10 & .12 & $<.05$ \\
6-10 vs 11 and above & $(2.88-3.72)$ & \\
Professional development & 1.7 & $<.01$ \\
$0-5$ vs 11 and above & $(4.40-3.72)$ & \\
6-10 vs 11 and above & 0.35 & $<.01$ \\
& $(2.88-3.72)$ & \\
\hline
\end{tabular}

\section{Discussion}

The findings from this study brought to light many important issues related to the application of NPST. Overall, teachers tended to rate themselves low or moderate in the extent to which they implemented the NPST. With regard to "standard of education in Jordan" teachers tended to rate themselves high on implementation. One possible interpretation for this could be that teachers, during their pre-service and in-service training courses, were provided solid knowledge about the education system in Jordan.

On the "Teachers Professional Ethics Standard," teachers also tended to rate themselves high on implementation. This result is to be expected since this standard is practiced widely by most of the teachers. Historically, teachers' work has been considered moral work. The ethics standard stresses the moral commitment of teachers as public employees entrusted by society. This trust requires teachers to adhere to a moral standard of conduct where teaching is guided by high ethical standards. However, for the rest of the standards, teachers tended to rate themselves low or moderate in implementation.

Furthermore, results regarding the "Content and Special Pedagogical Knowledge Standard" indicated that increasing teachers' content knowledge of their discipline and their expertise in pedagogical content knowledge are both challenging and overwhelming to Jordanian teachers. These problems are likely to exist because few efforts in Jordan have provided time and training courses for teachers to develop mastery of new content or skills required for new standards.

The "Lesson Planning and Implementing Standards" by which teachers have been expected to meet the demands of the new requirements seem to have been implemented only at a lower level. This result might reflect the fact that Jordanian teachers were not involved in curriculum development and, hence, find it hard to change their teaching behaviors (Alwakeel, 2009).

Regarding the "Assessment of Students Learning Standard," this standard asks teachers to reconceptualize their role as evaluators to try to ensure that they assess their students' 
performance in more reliable and valid ways using different assessment styles that focus on higher thinking skills and to use these assessments as feedback for the improvement of their own teaching (World Bank, 2009). In the past, Jordanian teachers have been criticized for using assessment styles that stress only memory and direct recall of information in their students' evaluations (Alkarasneh, 2007).

Regarding the "Professional Development Standard" it is critical that teachers are provided professional development that enables them to make their teaching more effective and to address any barriers that may be impeding their application of NPST efforts. According to NPST, teachers should be lifelong learners, seeking to incorporate Information Communication Technologies (ICT) in their daily practice, while gaining new knowledge and skills to meet the diverse needs of their students. However, as the results indicate, teachers are not succeeding in incorporating this ICT into their daily practice. Teachers fear that ICT will dramatically shift traditional education into a new pedagogical environment where teachers are not adequately familiar with its objectives, content, and learning outcomes (Abuhmaid, 2009; Zaidiyeen, Mei \&Fook, 2010; Akour \& Shannak, 2012).

For many years the MOE held the same training courses for all teachers. This large-scale training was highly theoretical and often failed to address the specific problems that teachers were facing (UNDP, 2004). This situation appears to confirm Fullan's argument that professional development "is still too divorced from the life of organization, not yet organically connected to every day work" (Fullan, 2000, p.6).

As a result, teachers said they were unprepared and unable to cope with diversity in their classrooms. They did not have the capacity to manage different levels of student ability in their classes. The results indicated also that differences were not found between male and female teachers. This finding may be explained in light of the fact that both male and female teachers at Northern provinces schools receive the same courses and are working in the same conditions.

The findings indicate that veteran teachers may be less effective than their less-experienced counterparts, which suggests that Ministry of Education should consider strategies to encourage high application of NPST. Perhaps experienced teachers are not staying abreast of the latest curricular and pedagogical advances, or that the decline in the application of NPST could simply be a function of teacher resistance to the changes mandated by NPST. Either way, targeted professional development and reward structures should be in place to encourage the ongoing development of teachers' skills that will enable them to apply NPST most effectively.

\section{Conclusion and Recommendations}

Teachers' experiences with students make them essential participants in the design, development, interpretation, and implementation of NPST, which was prepared by experts outside of the classroom. Teachers-involvement helps to ensure congruence of the classroom practice of education. However, after JERP was implemented, teachers were then faced with problems. They found that they have to work with an unfamiliar structure and they feel they 
have no sense of ownership because they have not been part of the decision making process for the implementation of this change especially the professional standards ingredient. Moreover, because these standards represented a radical shift in the working and thinking of teachers, they needed a long gestation period in order for the MOE to publicize the changes and gain their acceptance by the teachers and community.

The new challenge that faces teachers appears to be a most complex one as they are required to apply new standards that place a considerable burden on their shoulders. Furthermore, engaging stakeholders (i. e., subject matter experts, teachers, educators, parents) in the process of implementing these standards insures a high rate of standards implementation. The Ministry of Education should be playing a larger role in building awareness of the standards and how they will impact teachers work. It is important to show teachers how to connect their work to specific standards for student performance. Finally, based on the limited sample in this study, further research is necessary to examine teachers' perceptions on the national level. An empirical study of pre-service teachers in educational faculties in Jordanian universities also appears to be warranted.

\section{References}

Abuhmaid, A. (2009). ICT integration across education systems experience of Jordan educational reform. Saarbrücken: VDM Verlag.

Akour, M., \& Shannak, R. (2012). Jordan education reform for the knowledge economy support project- a case study. Journal of Management Research, 4(4), 116-130.

Alayan, S., Rohde, A., \& Dhouib, S. (2012). The politics of education reform in the Middle East. Oxford: Berghahn.

Alkarasneh, S. (2007). The constraints of using non-traditional teaching procedures in teaching social studies. Jordanian Journal of Educational Sciences, 3(2), 125-141.

Alshawa, H. (2012). Investigating the implementation degree of the teacher professional standards in mathematical educational: Courses from the pre- services teachers perspectives in Jordan. International Journal of Humanities and Social Sciences, 2(12), 89-97.

Alshorfat, S. (2012). The impact of a mandated educational reform program on Jordanian teachers' work lives. International Journal of Applied Educational Studies, 12(1), 57-70.

Alwakeel, D. (2009). Teachers voice in Jordanian educational change strategy. Jordan Times, October 23, A21, A26.

Blatchford, R. (2013). The 2012 teachers' standards in the classroom. Exeter: Learning Matters.

Board of Teacher Registration, Queensland. (2002). Professional standards for graduates and guidelines for preservice teacher education programs. Toowong, Queensland: Board of 
Teacher Registration.

Brocks, P. (2000). Standards of professional practice for accomplished teaching in Australian classrooms: A national discussion paper. Canberra: Australian College of Education, Australian Curriculum Studies Association and Australian Association for Research in Education.

Bulmahn, E. (2004). National education standards as part of a comprehensive quality management system in schools. European Education, 15(4), 21-25.

Caldwell, B.J. (2010). The impact of test driven accountability. Paper presented at the Annual General Meeting of the Victoria Principals Association, 26 November, Melbourne, Australia.

Comber, B., \& Nixon, H. (2009). Teachers' work and pedagogy in an era of accountability. Discourse: Studies in the Cultural Politics of Education. 30(3), 333-345. http://dx.doi.org/10.1080/01596300903037069.

Creswell, J. W. (2013). Research design: Qualitative, quantitative and mixed approaches, $\left(4^{\text {th }}\right.$ ed.), Upper Saddle River, NJ: Pearson.

Cuban, L. (2007). The never ending quest: Lesson learned from school reform.Education Week, 26(29), 28-29.

Daraiseh, A. (2014). The degree of science teachers' commitment at national professional teaching standards in the light of some variables. Journal of Hebron University for Research and Studies, 9(2), 139-163.

Darling-Hammond, L. (2004). Standards, accountability, and school reform. Teachers College Record, 106(6), 1047-1085.

Eberts, R., Hollenbeck, K., \& Stone, J. (2002). Teacher performance and student outcomes, Journal of Human Resources. 37(4), 913-927. http://dx.doi.org/10.2307/3069621

Fowler, F. (2013). Survey research methods (applied social methods). ( $\left.5^{\text {th }} \mathrm{ed}\right)$, London: Sage.

Fraenkel, J. R., \&Wallen, N. E. (2006). How to design and evaluate research in education. $\left(6^{\text {th }}\right.$ ed.). New York: The McGraw-Hill Companies, Inc.

Frey, C. (2014). "A geography of education reform: Imports, exports and the "Jordan Model". Paper presented at the annual Conference of the Comparative and International Education Society, November, 30 Charleston, South Carolina.

Fullan, M. (2000). The return of large-scale reform. Journal of Educational Change, 1(1), 5-28. http://dx.doi.org/10.1023/A:1010068703786

Fullan, M. (2001). The new meaning of educational change ( $3^{\text {rd }}$ ed.). New York: Teachers College Press.

Giroux, H. (2008). Against the terror of neoliberalism: Politics beyond the age of agreed. Boulder Co: Paradigm. 
Hargreaves, A. (2009). A decade of educational change and a defining moment of opportunity-an introduction. Journal of Educational Change, 10(20), 89-100. http://dx.doi.org/10.1007s/10833-009-9103-0.

Hargreaves, A., Lieberman, A., Fullan, M., \& Hopkins, D. (1998). International handbook of educational change: Part one. Dordrecht: Kluwer Academic Publishers. $\mathrm{http}: / / \mathrm{dx}$. doi.org/10.1007/978-94-011-4944-0.

Hargreaves, A., \& Goodson, I. (1996). Teachers' professional lives: A spirations and actualities. In I. Goodson \& A. Hargreaves, (Eds.) Teachers' professional lives (pp.1-27), London: Falmer.

Harris, J., Moran, W., \& Long, J. (2010). Teacher educators respond to the NSWIT professional teaching standards: A case study of a school-university partnership. Journal of Catholic School Studies, 82(2), 40-58.

Ingvarson, L., \& Kleinhenz, E. (2006). Standards for advanced teaching: A review of national and international developments. Acton, ACT: Australian Institute for Teaching and School.

Kelchtermans, G. (2007). Teachers' self-understanding in times of performativity. In L. F. Deretchin, \& C. J. Craig (Eds.), International research on the impact of accountability systems, (pp.13-30). Teacher Education Yearbook 15. Lanham, MD: Rowman\& Littlefield.

Kubow, P.K. (2010). Constructing citizenship in Jordan: Global and local influences shaping the national narrative in the Education Reform for Knowledge Economy (ERfKE) Era. World Studies in Education, 11(1), 7-20. http://dx.doi.org/10.7459/wse//11.1.03

Meiers, M. (Ed.). (2006). Teachers' stories-professional standards, professional learning: Using STELLA as a framework for professional learning. Norwood, SA: Australian Literacy Educators' Association.

Ministry of Education, (2013). Education reform for the knowledge economy, second phase, annual narrative report. Amman: Ministry of Education.

Ministry of Education. (2006). National teachers professional standards. Amman: Author.

Ministry of Education. (2012). National education reform conference. Amman: Ministry of Education.

Nasta, T. (2007). Translating national standards into practice for the initial training of Further Education (FE) teachers in England. Research in Post-Compulsory Education, 12(1), 1-17. http://dx.doi.org/10.1080/13596740601155223

OECD, (2012). Teachers for the XXI century, using evaluation to improve teaching; Background Report for the 2013 International Summit on the Teaching Profession, Paris: OECD Publications.

Olson, L. (2007). Standards get boost in the hill. Education Week, 26(19), 1-25. 
O'Shea, M. R. (2005). From standards to success. Alexandria, VA: Association for Supervision and Curriculum Development.

Phoenix Center for Economics and Informatics Studies (2014). Improving the quality of primary public education in Jordan. Amman: PCEIS.

Portrt, R., Fursarelli, L., \& Fursarelli, B. (2015). Implementing the common core: How educators interpret. Educational Policy, 29(1), 111-139.

Quota, M. (2014). What schools in Jordan teach us about educational reform between the ideal. Switzerland: World Economic Forum.

Reynolds, C. (2005). No teacher left untested: Historical perspectives on teacher regulation. In N. Bascia (Ed.), International handbook of educational policy. Dordrecht: Springer.

Romanowski, M. (2014). A Habermasian analysis of Qatar's national teacher professional standards, International Journal of Education, 6(1), 108-127. http://dx.doi.org/10.5861/ijrse.2014.664

Sachs, J. (2003). Teacher professional standards: Controlling or developing teaching? Teachers and Teaching, 9(2), 175-186. http://dx.doi.org/10.1080/13540600309373

Sakarneh, M. (2014). Jordanian education reform between the ideal and the actual, Developing Country Studies, 4(20), 61-71.

Santoro, N., \& Kennedy, A. (2015). How is cultural diversity positioned in teacher professional; standards? An international analysis. Asia-Pacific Journal of Teacher Education, 43(3), 183-194. http://dx.doi.org/10.1080/1359866X.2015.1081674.

Shirazi, R. (2010). "Trafficking modernity: A critical engagement with transnational narratives of development and education reform in Jordan". Paper presented at the annual meeting of the Comparative and International Education Society, 28 February, Chicago.

Sonbol, A. (2003). Women in Jordan: Islam, labor and the law. Syracuse: Syracuse University Press.

Spring, J. (2009). Globalization of Education. New York: Routledge.

Storey, A. (2006). The search for teacher standards: A nationwide experiment in the Netherlands. Journal of Education Policy, 21(2), 215-234. http://dx.doi.org/1080/02680930500500427.

Townsend, T., \& Bates, R. (Eds.). (2007). Globalization, standards and professionalism in times of change. Dordrecht: Springer.

Tuinamuana, K. (2011). Teacher professional standards, accountability, and ideology: Alternative discourses. Australian Journal of Teacher Education, 36(12), 72-82. http://dx.doi.org/10.14221/ajte.2011v36n12.8

United Nation Development Program. (2004). Toward freedom in the Arab world. The Arab Human Development Report. Amman: National Press. 
Wise, A. (2004). NCLB's unintended consequences, Quality Teaching Newsletter.

Witte, T., \& Jansen, E. (2015). In search of the excellent literature teacher. An inductive approach to constructing professional standards. Teachers and Teaching: Theory and Practice, 21(5), 565-583. http://dx.doi.org/10.1080/13540602.2014.995478.

World Bank. (2009). Education reform for knowledge economy project. Implementation and result report. Washington DC: World Bank.

Zaidiyeen, N., Mebi, L., \& Fook, F. (2010). Teachers' attitudes and levels of technology use in classrooms: The case of Jordan schools. International Education Studies, 3(2), 211-218.

\section{Copyright Disclaimer}

Copyright for this article is retained by the author(s), with first publication rights granted to the journal.

This is an open-access article distributed under the terms and conditions of the Creative Commons Attribution license (http://creativecommons.org/licenses/by/3.0/). 